\title{
The Politics of Treaty Signature: The Role of Diplomats and Ties that Bind
}

\author{
Manfred Elsig \\ University of Bern \\ World Trade Institute \\ manfred.elsig@wti.org
}

\author{
Karolina Milewicz \\ University of Oxford, \\ Department of Politics \& International Relations \\ karolina.milewicz@politics.ox.ac.uk
}

\begin{abstract}
The literature on international cooperation through legal commitments focuses chiefly on treaty ratification. What has received much less attention is that before states ratify treaties, they commit to treaties through the act of signature. This paper addresses this research gap by investigating how a state's decision to sign a treaty is affected by its diplomatic representation during treaty negotiations. Conceptualizing signature as a commitment step, we argue that participation in treaty negotiations translates into a "ties-that-bind" effect creating incentives for diplomats to support the treaty text leading to treaty signature. Our empirical analysis uses a new data set on signature and tests the argument for 52 multilateral treaties concluded between 1990 and 2005. Results confirm that participation in treaty making matters for signature but not necessarily for ratification.
\end{abstract}

Keywords: treaty signature, ratification, diplomatic representation, treaty making.

Acknowledgements: Earlier versions of the paper were presented at the International Studies Association Annual Meeting in Montreal in 2011, at the Hamburg Lectures on Law and Economics, University of Hamburg in 2011, at the 5th Annual Conference on the Political Economy of International Organizations, Philadelphia in 2012, the Annual Conference of the Swiss Political Science Association, University of Zurich in 2013, and the Global Economic Governance seminar, University of Oxford in 2014. Special thanks go to Tobias Böhmelt, Stephen Chaudoin, Bob Goodin, Justin Leinaweaver, Gabriele Spilker, Kendall Styles and Alex Thompson for comments. We particularly wish to thank Samuel Rohr and Christian Metzger for research assistance. We acknowledge financial support from the NCCR Trade Regulation (www.nccr-trade.org). 


\section{Introduction}

In 2001, after terrorist attacks hit New York, the activities at the United Nations (UN) headquarters directed towards combatting terrorism markedly increased. Not only did UN diplomats revitalize negotiations on a comprehensive anti-terror convention, they also encouraged their capitals to sign up to already existing anti-terror conventions. Within the three months that followed the terrorist attacks the number of signatories to the International Convention for the Suppression of the Financing of Terrorism, adopted by the General Assembly back in 1999, increased from 42 to 131 (Szasz, 2002: 903). ${ }^{1}$ The 9/11 experience created a strong consensus among negotiators based in New York regarding the necessity to strengthen international anti-terrorist law, initially by signing this Convention. Such enthusiasm for signature was, however, not fully matched in the home states of the negotiators; ratification of the convention dragged on in a significant number of signatory states. This example suggests that the decision to sign a treaty can be driven by the perceptions and interests that develop among diplomats based abroad.

In this paper we examine more systematically the role of diplomats in the decision to sign multilateral treaties. We argue that participation in multilateral treaty negotiations creates a ties-that-bind effect among diplomats that, in turn, increases their propensity for treaty signature. Being more involved in the drafting of the treaty and having a hand in writing treaty law, diplomats are more likely to accept a treaty. Therefore, the greater their participation in treaty negotiations, the more they will support treaty content and advocate treaty signature.

Investigating the role of diplomats with respect to the politics of treaty signature, we make two contributions to the existing scholarship on international treaty making. First, the literature on international legal cooperation focuses nearly exclusively on why states ratify

\footnotetext{
${ }^{1}$ The treaty has been open for signature since December 1999 (United Nations Treaty Collection, 2014).
} 
international treaties, but neglects entirely that ratification is usually preceded by signature (for exceptions see Goodliffe and Hawkins, 2006; Leinaweaver, 2012). By focusing on "signature" we question the commonly held view that signature is of purely symbolic nature (Recchia, 2002). We posit that signature is not only a commitment "to refrain from acts that would defeat the object and the purpose of the treaty" (Vienna Convention on the Law of Treaties, 1969, Art. 18a), but that it is also a deliberate and decisive step towards making binding commitments.

Second, by focusing on the role of negotiators in international treaty making we also contribute to the literature on diplomacy in international politics. While most analytic work on diplomacy in international cooperation studies political leaders (e.g. Hollyer and Rosendorff, 2012; Rathbun, 2011), there is surprisingly little research on the impact of state officials and diplomats on international legal cooperation (e.g. Johnson, 2013).

Empirically, we capture the ties-that-bind effect on treaty signature with the extent of diplomats' participation in treaty making. We expect that the greater the diplomatic involvement, the more likely it is that the ties-that-bind effect will occur. Our analysis indicates that participation during negotiations does indeed promote signature, but does not translate into prompt treaty ratification. For the latter, domestic factors are more important than the ties-that-bind effect at the international level.

In the next section we elaborate on the neglected role of treaty signature. In section 3 , we outline our argument. This is followed by a more systematic empirical test of treaty signature and ratification based on a data set of 52 post-Cold War multilateral treaties. We conclude with an outlook for the politics-of-signature research agenda. 


\section{The Neglected Study of Signature}

Treaty signature has not received much attention in the study of international cooperation. International law scholars attribute limited value to signature as a commitment device as it does not impose explicit binding obligations upon states (Vienna Convention on the Law of Treaties, 1969, Art. 18). It is primarily perceived as a means of treaty authentication and an expression of a state's willingness to continue the treaty-making process toward ratification (United Nations Treaty Collection, 2015). We contest this characterization of treaty signature, and instead conceptualize it as a non-trivial decision that can put pressure on ratification bodies at home. While signature does not guarantee ratification, it nevertheless creates an institutional pathway towards eventual ratification.

Usually, executives are expected to forward the treaty for approval to national legislatures for ratification. If legislative bodies abstain from ratifying a signed agreement, they have to provide convincing reasons for that decision to the domestic constituencies and treaty partners, knowing that non-ratification will endanger cooperation and inflict reputational costs on them (see Sartori, 2005; Tomz, 2007). Anticipating this pressure, ratification bodies sometimes publicly call for their inclusion in the decision to sign a treaty which is usually a prerogative of the executive. In the complex negotiations of Iran's nuclear program, for instance, questions over the necessity to get a skeptical US Congress' approval for signing an agreement were hotly debated (New York Times, 2015). Signature is more than a gesture; it is a type of pre-commitment that goes beyond an international "promise not to undermine the treaty" (Guzman, 2008: 178).

Besides putting pressure on the ratification body, signature has also been used at times to pursue specific political objectives domestically and internationally. The US government signaled to important constituencies that it represents their interests, such as in the case of the Clinton Administration signing the Kyoto Protocol to combat global warming (The 
Washington Post, 1997). The same government signed the Rome Statute of the International Criminal Court in order to have a say in the future developments of the court (American NonGovernmental Organizations Coalition for the International Criminal Court, 2008).

A look at signature and ratification patterns of 52 multilateral treaties adopted between 1990 and 2005 also suggests that signature as a commitment device is distinct from ratification. Table 1 presents the top ten ratifying and signatory states. What is most striking about these figures is that the overall signature and ratification rankings are markedly different. While newly democratized states in Eastern Europe spearhead the ratification ranking, established western democracies are almost exclusively the leading nations when it comes to signing multilateral treaties. ${ }^{2}$

[Table 1 about here]

These distinct empirical patterns provide an additional incentive to study the question of why states sign multilateral treaties more systematically as different factors might drive states' incentives to sign and ratify treaties. Past research has treated signature as an implicit act exploring the time that elapses between signature and ratification (e.g., Haftel and Thompson, 2013). Few scholars focus on signature as the main outcome. We expand on this nascent scholarship on signature following in the footsteps of Goodliffe and Hawkins (2006) who analyze the Convention against Torture, and Leinaweaver (2012) who focuses on environmental treaties, and explore the role of diplomats for treaty signature.

\section{How Participation Matters for Signature}

While multilateral treaty making involves a long delegation chain with many actors (from the voter to the national government to the IO staff), we pay particular attention to one important group of actors: the diplomats representing states in international institutions or in

\footnotetext{
${ }^{2}$ Denmark, Norway and Spain rank high both for ratification and signature.
} 
treaty negotiations (Nielson and Tierney, 2003). These (mostly non-elected) diplomats may be either based at the country missions to the respective United Nations agencies (e.g., in New York, Geneva, Vienna, Nairobi, or Bonn) or recruited from the competent government departments or offices (e.g. as in the case of environmental treaties). They are the key actors working with and within international institutions, and as such serve as agents of the competent government departments or offices which are run by politically appointed leaders. Those government departments are responsible for defining the overall negotiation mandate, giving approval to sign a treaty and managing the ratification of international treaties. ${ }^{3}$

Diplomats actively influence governmental decisions to sign but do not typically play a role in the ratification process. Owing to their involvement in the negotiations, they are in a strong position to persuade governments to advocate (or discourage) the signing of an agreement. They may use their diplomatic skills and information advantage to address concerns raised by political leaders regarding the meaning, interpretation or opt-outs of the treaty. Diplomats become less central once the treaty is discussed in the domestic arena (e.g., parliaments and the wider public) with a view to ratification. ${ }^{4}$ At this stage, governments and various domestic veto players, such as opposition parties, interest groups and nongovernmental organizations, gain more prominence in this process.

Next, it is important to note that most multilateral treaty negotiations usually take place under the auspices of formal IOs which are characterized by consensual decision making. A consensual rule provides incentives for every diplomat present during negotiations to propose treaty text and it limits the possibility that negotiators will be ignored by other

\footnotetext{
${ }^{3}$ The order to sign an agreement generally comes from the relevant government department (and its competent office). The ratification bodies differ across states.

${ }^{4}$ Diplomats usually do not play a central role in directly promoting the treaty to the ratification bodies at home (Thuysbaert, 2006). Often it is even seen as counterproductive to have diplomats participating in ratification debates.
} 
delegations. Consensus alleviates, to a certain extent, the abuse of power in negotiations, and it also helps build a sense of community and a common concern for an issue.

Building on the above assumptions about the nature of treaty negotiations and the role and position of diplomats in this process, we explore how the decision to sign is driven by diplomats' involvement in treaty making. Participation produces a ties-that-bind effect that positively influences diplomats' incentives to create support for the negotiated treaty, and in turn pushes them to persuade their governments to sign. This ties-that-bind effect in support of the agreement develops over the course of negotiations and materializes in two forms: 1) diplomats' personal contributions to and investment in the content of the treaty (ties with the text), and 2) diplomats' mutual expectations that the treaty reflects a compromise based on concessions (ties with the diplomatic community). ${ }^{5}$ We next elaborate on these two mutually reinforcing pathways in more detail and provide illustrations drawn from diplomats involved in negotiating the Cartagena Protocol on Biosafety.

First, contributing to the drafting of a treaty text can yield personal benefits for a diplomat. She is trained in the art of negotiations and bargaining over treaty texts presents her with a strategic opportunity to apply her skills. By doing this well, a diplomat can strengthen her position within the foreign affairs department as an able negotiator and can thus improve her career prospects. Because a negotiator profits from reaching an agreement that she helped to shape, she will have a strong desire to be influential in negotiations. The more a diplomat has a hand in drafting the treaty (e.g., tabling proposals), the greater her overall support for the treaty text and therefore the stronger the ties-that-bind effect. At the end of the negotiations a diplomat can see her own imprints on the actual treaty text. Such selfidentification represents to a diplomat the result of hard work measured in numerous hours

\footnotetext{
${ }^{5}$ Our argument differs from contributions that focus on how shared norms affect behavior or how interaction and socialization lead to shifts in preferences, which could account for agent slippage (Johnston, 2001; Checkel, 2005).
} 
spent on finding solutions to contentious issues. The approval of the agreement by the government furthermore reinforces the diplomat's perception of her personal investment in and impact on the treaty text, confirming that she did her job well.

While it is difficult to observe this type of ties with the text effect directly, the personal reflections of former negotiators illustrate that active involvement in treaty drafting strengthens acceptance of the final outcome. It is common practice in international negotiations for diplomats to be invited to propose treaty language as part of a collective effort to reach consensus. In the case of the Cartagena Protocol on Biosafety the chair of the negotiations put forward a compilation of the negotiating parties' drafted positions (Falkner, 2002; Köster, 2002). Although most of the parties' propositions were inserted in "brackets" signifying that they had not yet been agreed upon, many of these passages made it into the final agreement.

Making textual contributions and seeing them in the draft treaty is satisfying for the diplomats involved. The Swiss chief negotiator, for example, emphasized the importance of providing input to the text for inclusion in the chairman's draft document (Nobs, 2002: 191). This allowed him and his team to consider the treaty in a more favorable light and impacted positively on the overall assessment of success. Also, treaty language that is close to ones' own textual suggestions gains that country's support. The deputy head of the Brazilian delegation noted that "Brazil was happy to see Article $11[\ldots]$ as it reproduces almost word for word the instructions the delegation had received [from the capital] but had hesitated to table" (Villanova Nogueira, 2002: 133). As a result, personal contributions and overall success often go hand in hand. Three of the EU negotiators who were involved stressed their ties to the treaty text following the conclusion of the negotiations. They concluded that "the EU negotiators felt deep satisfaction, considering that they had contributed to the result and 
that the EU's negotiating strategy had been successful" (Bail, Decaestecker and Jorgensen, 2002: 185).

Second, participation in negotiations can also lead to concession trading between diplomats. Package deals in multilateral negotiations constitute a fine balance between the gains and losses of the parties involved. Concessions in some areas are offset by gains in others. Over the course of negotiations the diplomats' mutual expectations about the envisaged outcome of the treaty rise since the deals on the table are perceived as an offshoot of fair compromise that should be "executed". Lax and Sebenius (1986) describe this phenomenon as a "relationship" interest which leads to "self-restraint [...] motivated by a sense of responsibility or obligation [...] especially to protect" (Lewis, 2005: 492). Sudden defection (including potential reluctance to sign a deal) would only be accepted under special circumstances that any negotiator may face (e.g., an external shock to the negotiations such as a regime change at home, or some unanticipated developments that impact the assessment of the draft treaty text). Thus, the ties bind negotiators with each other in ways that make it harder for them to escape.

With respect to the negotiations of the Biosafety Protocol, Cameroon's head of delegation stressed that "the protocol is so balanced that it is capable of serving the needs of all countries" (Yang, 2002: 77). The deputy-head of the Brazilian delegation also alluded to this fine balance remarking that "those who expected to have their constituencies' agendas fully reflected in the text were naturally frustrated, but, as the diplomatic saying has it, a good negotiation is one in which all participants feel somewhat frustrated at the end" (Villanova Nogueira, 2002: 137). The relational aspect was stressed in particular by a Canadian delegate to the negotiations who recalled that "personal relationships did develop and proved particularly useful [...] in overcoming differences" (Ballhorn, 2002: 114). ${ }^{6}$

\footnotetext{
${ }^{6}$ It is not unusual for intense negotiations to result in long-term friendships (Bartos, 1996).
} 
Both ties-that-bind pathways can also be summarized with what negotiation theory calls "the sunk costs of long bargaining and the relationships built up with the other sides [...]" which "may lead the engaged agent to seek 'something' to show for the labor" (Lax and Sebenius, 1986: 309). We expect that the ties-that-bind effect is more likely to occur, the greater the participation of the diplomatic corps during treaty negotiations. Those who have been participating all along in the drafting of the treaty and have done so through larger delegations are more inclined to accept the final treaty package negotiated. Since negotiations of multilateral treaties, such as in the case of the Biosafety protocol, usually proceed in parallel drafting sessions addressing different and specialized issues of a given treaty, large delegations are more able to participate in a greater number of drafting groups or committees, which in turn increases their contribution and hence their buy-in. ${ }^{7}$ Consequently they advise their governments to sign, partially filtering out concerns over ratification. This translates into a swift signature. We propose that:

The likelihood of treaty signature increases with the size of the diplomatic mission in treaty negotiations.

Whereas we conjecture that participation affects signature because of the ties-thatbind effect, we do not expect participation in negotiations to systematically matter for ratification. The literature so far has shown that domestic politics strongly affect ratification; however, treaty negotiators are often far removed from domestic politics and they play a marginal role in ratification. In addition, non-ratification of a treaty can be attributed to unexpected events (e.g., regime change), ideological constellations of the parliament or constitutional interpretation of international law (e.g., in the case of the United States). As Haftel and Thompson show for bilateral investment treaties, a large number of treaties remain unratified. These authors find that "failure to anticipate obstacles is most likely to occur when

\footnotetext{
${ }^{7}$ In his book on „Ozone Diplomacy“ Benedick (1998) also emphasizes the importance of small-group negotiations, informal meetings and selective subcommittees for consensus-building. Larger delegations can be especially influential by taking advantage of such negotiation strategies.
} 
political systems are unpredictable and when governments have difficulty discerning obstacles in the partner" (2013: 357-358). We suggest that diplomats are often unable to anticipate obstacles to domestic ratification, not least because of a strong ties-that-bind effect. $^{8}$ Therefore participation should not significantly affect ratification.

\section{Empirical Analysis}

\section{The dependent variable: Time to signature (and ratification)}

In this paper we focus on patterns of treaty signature and compare them to patterns of treaty ratification. The comparison enables us to assess whether diplomatic involvement in treaty negotiations has a different impact on signature than on ratification. To do so, we use quantitative methods and draw from an existing data set of 76 multilateral treaties concluded between 1990 and 2005, and which meet the following three criteria: First, they are universal; they offer participation to all recognized states in the world. This condition excludes all plurilateral treaties (e.g., NAFTA), which are often defined as multilateral. Second, they address global concerns. This excludes treaties that are open to all states in terms of membership, but have a regional focus regarding the subject matter of the treaty (e.g., conventions under the auspices of the UN Economic Commission for Europe). As these treaties typically address global public goods, they are of interest to all parties. Third, they depart from previous practice. This disqualifies treaties that merely reflect adjustments to a pre-existing treaty (e.g., different reporting requirements or the addition of minor areas of application).

We eliminated treaties that do not foresee two clearly separable commitment steps signature and ratification - but which provide for accession only (e.g., WTO treaties). We also excluded treaties of private international law character (e.g., Hague Private International

\footnotetext{
${ }^{8}$ This is not to say that negotiators can never anticipate the legislature's reaction to a negotiated treaty. But if anticipation was perfect we would not observe failed ratification.
} 
Law conventions or International Institute for the Unification of Private Law (UNIDROIT) conventions), as these treaties are drafted and negotiated by private international law experts and scholars rather than state representatives. Our data set includes 52 public international law treaties covering diverse issue areas, such as human rights, security, crime, trade and environment (for an overview of the selected treaties, see Table 4 in the Appendix). The data set provides signature and ratification entries made by states between 1990 and 2008 which describe the change in status from non-signature/non-ratification to signature/ratification by a given state in calendar years.

\section{The key explanatory variables: Size of diplomatic mission}

To offer a more systematic account of the participatory ties-that-bind effect in international negotiations we do not differentiate between the two ties-that-bind pathways, but apply two proxies both of which capture the extent of participation during treaty negotiations.

The first variable UN DIPLOMATIC REPRESENTATION is a general approximation of diplomatic involvement in the domain of the United Nations (UN). It reflects the size of the state missions to the UN in New York, and is based on information from UN Blue Books available for the period 1990 to 2008. This variable is time-variant but constant across treaties; it is available for all 52 treaties. ${ }^{9}$

While UN DIPLOMATIC REPRESENTATION is constant and not subject to negotiationspecific changes, our second proxy TREATY-SPECIFIC DIPLOMATIC REPRESENTATION is a more direct measure of participation in actual treaty negotiations. We assume that in consensual decision-making fora the size of representation translates into more participation and input,

\footnotetext{
${ }^{9}$ We are aware that a state's mission to the UN in New York is not truly representative of the state's actual delegation during specific treaty negotiations, but it provides a useful proxy that is not so far off the treatyspecific delegation size. This is also confirmed in our analysis below.
} 
and therefore increases the ties-that-bind effect. ${ }^{10}$ Whereas this variable is more closely related to specific treaty negotiations and therefore offers a better measure for our purposes, such information is in general less often available. We therefore constrained our search of participation-related information to treaties that are particularly salient. In order to determine "saliency", we googled all 52 treaties by their full titles, rating treaties with 200,000 Google hits or more as salient. ${ }^{11}$ In this way we identified a subset of 19 salient treaties, and we were able to retrieve negotiation-related information on the size of the diplomatic delegations for 13 of these salient treaties. As the size of a national delegation can vary throughout the negotiation process, we collected information on the size of the delegation at the outset of negotiations from participants' lists. ${ }^{12}$ If such information was not accessible we relied on available information from the next negotiation session.

Studying the subset of salient treaties presents a more demanding test for our ties-thatbind argument. In the case of salient treaties, political leaders will attempt to control the negotiation behavior of diplomats because of the political implications at home. This is not so much the case for less salient treaties where ties-that-bind incentives can develop more easily. Further details on the salient treaty sub-sample and availability of treaty-specific participation information are provided in Table 4, Appendix. We expect the likelihood of signing a treaty to increase with the size of the state delegation participating in treaty negotiations. The

${ }^{10}$ A small negotiation team also is hampered by the fact that in most treaty negotiations various drafting committees meet at the same time. Therefore providing input on all the sub-issues is more difficult for small delegations and decreases their overall buy-in.

${ }^{11}$ We also used two alternative thresholds: 100,000 and 150,000. For an argument on how the Google search engine captures the degree of political mobilization and therefore saliency, see Pelc (2013).

12 The size of delegation in treaty-specific negotiations is also affected by financial constraints, in particular for developing countries who often are dependent on support from the organizing or negotiation bodies. Sometimes developing countries also send diplomats from local embassies who are less skilled than diplomats from the capital. Some of these concerns can be addressed through trust funds set up to encourage participation of least developed counties especially. Host countries and their neighbouring countries also tend to have greater participation. Thanks to a reviewer for pointing this out. 
distribution of the variables and rankings for the top ten states in terms of representation are presented in Figure 1 and Table 5, Appendix.

\section{Controls}

In our models, we also test for alternative explanations prominent in the commitment literature, which may apply to signing. Democracies are generally expected to be more likely than non-democracies to commit to multilateral treaties. We therefore test for the regime type of a state employing the polity2 score from the Polity IV index (POLITY). The scale ranges from -10 (strongly autocratic) to +10 (strongly democratic), and measures the domestic regime type of a given state, reflecting the underlying political (democratic versus authoritarian) values, structures and institutions of a society (Marshall, Gurr and Jaggers, 2014).

Because negotiators might try to address domestic obstacles to ratification and aim first and foremost to get agreements accepted domestically, we control for domestic ratification constraints (POLCON). Following our proposition, however, we expect such constraints to have less effect on treaty signature than on treaty ratification. We use the Political Constraints Index V (Henisz, 2000).

Since newly created states are particularly interested in building reputation, they might well sign treaties without having participated in the negotiations. Signing could be a strategy deliberately adopted by newer states that gained independence in the 1990s to increase their international standing. Therefore, we use a dichotomous variable POST-1989 STATE that captures whether a state has been formed after 1989 or before. It controls for the potentially higher pace of commitment by states that gained independence after the collapse of the Soviet Union in 1989. 
Next, to test that the size of diplomatic representation does not merely reflect a state's power, we control for the state's material capabilities using the Composite Index of National Capability (CINC) (Correlates of War Project, 2005). CINC and UN DIPLOMATIC REPRESENTATION are highly correlated (0.858), whereas CINC and TREATY-SPECIFIC DIPLOMATIC REPRESENTATION display a low correlation of 0.21 indicating that treaty-specific delegation size is not a function of powerful states' ex ante interest in multilateral treaties. In other words, greater participation and more influence during negotiations - which we expect to lead to signature - are not endogenous to the more powerful states' interests in treatymaking.

Similarly, to capture whether the size of the diplomatic mission reflects the ability of richer states to send more diplomats to represent their interests in treaty negotiations than poorer states, we also include GDP PER CAPITA (GDP P.C.) (relying on the purchasing power parity basis in US dollars) into our models (Central Intelligence Agency, 2008). It is noteworthy that GDP P.C. is not significantly correlated with the size of diplomatic representation: 0.185 with TREATY-SPECIFIC DIPLOMATIC REPRESENTATION and 0.357 with UN DIPLOMATIC REPRESENTATION. This again suggests that signature is not just a function of richer states' capacities to send more diplomats, and therefore having a greater say in the treaty content.

We also control for a state's legal order, distinguishing between a COMMON LAW and a civil law system (La Porta et al., 1999). Governments with a common law system are faced with greater dispersion of possible treaty interpretations, and are assumed to be more hesitant to commit to international law than states with a civil law tradition, whether through the act of signature or ratification (Simmons, 2009).

Finally, we capture regional and area-specific differences with a CATEGORICAL REGION variable distinguishing between four regions AMERICA, ASIA, AFRICA, EUROPE (the 
latter being the reference category). We also include binary variables for three major issue areas of treaties covered in our sample: HUMAN RIGHTS (including human rights, cultural and public health agreements), SECURITY (including security, crime and diplomatic relations), and ENVIRONMENT in order to test whether signature differs across issue areas. An overview of the variables as well as descriptive statistics is presented in Table 6 (Appendix).

\section{Estimation method and models}

To study treaty signature/ratification, we use event history techniques. Event history modeling allows us to analyze the timing of political change, i.e., the change in status from non-signature/non-ratification to signature/ratification. It not only considers which states sign or ratify treaties, but also takes into account that some states do so with different time lags. Event history techniques can be also applied to data with "multiple events per subject" (Therneau and Grambsch, 2000). Because we are interested in signature and ratification patterns spanning the entire treaty sample, we need to take into account that each state can ratify up to 52 treaties. To do so, we formulated our signature and ratification data as count data and set it up as annual intervals (Andersen and Gill, 1982). ${ }^{13}$ Clustering on states, we consider that treaty signatures/ratifications by a specific state are not independent, but are not bound to have experienced a prior event (Box-Steffensmeier and Jones, 2004: 158). ${ }^{14}$ Finally, the method allows us to deal with incomplete observations (left-truncated and right-censored data). ${ }^{15}$ An excerpt of our data is provided in Table 7 (Appendix).

\footnotetext{
${ }^{13}$ The count data is non-ordered, and is set up to accommodate all multiple events in one and the same time interval.

${ }^{14}$ Alternatively, we also clustered our data on treaties instead of states to account for potential correlation of signature/ratification patterns by treaty. This modification, however, did not alter our major results.

${ }^{15}$ Right-censoring applies to states that had not yet signed/ratified a particular treaty at termination of the analysis in December 2008. Left-truncation is determined by a delayed entry time of states, e.g. successor states of the Socialist Federal Republic of Yugoslavia and of the Soviet Union, as well as the Czech Republic and Slovakia.
} 
We use a Cox proportional hazards regression mode ${ }^{16}$ with the modified partial likelihood $^{17}$ for left-truncated and right-censored data (Tableman and Kim, 2004: 209-211). In the Cox proportional hazards model, the hazard rate is the measure of effect; it is the exponential of the regression coefficient $(\exp (\operatorname{coef})) .{ }^{18} \mathrm{We}$ account for correlated groups of observations (non-independence of multiple observations per state) with robust sandwich variance estimators based on a grouped jackknife.

\section{Findings}

Tables 2 and 3 present the findings of the Cox proportional hazards estimations for the event of signing and ratifying treaties, respectively. Models in the two tables include our key explanatory variable UN DIPLOMATIC REPRESENTATION. They are all based on the full sample of 52 treaties providing signature and ratification data for the period 1990-2008 and 193 states. Because some data are missing, not all explanatory variables are available for the entire period and for all states. Thus the sample size varies somewhat throughout the models.

Table 2 presents three models each for the event of signature (models 1-3) and the event of ratification (models 4-6) as the dependent variables. The composition of the ratification models corresponds to that of the signature models - they build on the same set of variables. As mentioned earlier, all models include the variable UN DIPLOMATIC REPRESENTATION capturing the size of a state's mission to the United Nations in New York. Models 1 and 4 control for regional effects of AMERICA, AFRICA and ASIA as compared to the

\footnotetext{
16 Since non-proportionality of the hazard rates might result in time dependence of individual covariates (implying that the effect of one or more covariates on the hazard increases or decreases over time), we tested for the proportionality of the hazard assumption. Results based on scaled Schoenfeld residuals indicate that the assumption of the proportional hazards is satisfied by all covariates. Model checks and data diagnostics are available from authors on request.

${ }^{17}$ The likelihood is approximated by the Efron method which is particularly accurate in dealing with tied data.

${ }^{18}$ A hazard rate of 1 indicates that the covariate has no effect on the event of signature or ratification. A rate of more than 1 indicates an increase in the rate of signature/ratification, and a rate of less than 1 indicates a reduction in the rate of signature/ratification. Any statement that a state is more likely to commit is also a statement that the state will commit earlier and vice versa.
} 
effects of EUROPE, and the issue areas HUMAN RIGHTS, SECURITY and ENVIRONMENT. In models 2 and 5 we test for the effect of POLITY, POST-1989 STATE, COMMON LAW and GDP P.C.. Models 3 and 6 bring together all controls from models 1 and 2, and models 4 and 5, respectively.

The most interesting result concerns the effect of UN DIPLOMATIC REPRESENTATION. Whereas we find a statistically significant and positive effect for UN diplomatic representation for the event of signature, we find no such effect for the event of ratification. ${ }^{19}$ The size of the state missions does not yield much explanatory power for treaty ratification. In contrast, the increase of a diplomatic mission by one representative (e.g. a change in the size of the state mission from 12 to 13 delegates) increases the likelihood of signing a multilateral treaty by between 0.8 percent (models 2 and 3) and 1.9 percent (model 1). Comparing the 10th and 90th percentiles of the UN DIPLOMATIC REPRESENTATION, we find that states with larger missions (here counting 19 representatives) are between 1.14 (model 2) and 1.37 (model 1) more likely to sign multilateral treaties than states with relatively small missions (having two representatives). The equivalent comparison between states with a diplomatic mission of 129 representatives (maximum) and states with no representatives (minimum) reveals that the likelihood of signature is between 2.65 (model 2) and 10.75 (model 1) times higher for the state with the maximum-size mission. To sum up, the size of diplomatic mission makes a considerable difference for the event of treaty signature.

\section{[Table 2 about here]}

The differential effect of UN DIPLOMATIC REPRESENTATION on signature versus ratification stands out even more against the very uniform and stable estimation results for the controls in the models. Throughout all the models POLITY has a positive and statistically significant effect on both treaty signature and ratification. The more democratic a state is, the more

\footnotetext{
${ }^{19}$ We obtained the same results for ratification and signature models with UN DIPLOMATIC REPRESENTATION lagged by one year.
} 
likely it is to commit to multilateral treaties. The same is true for regional effects as well as the issue areas of treaties. European states (REGION - CATEGORICAL) are significantly more likely to commit (sign and ratify treaties) than states in other world regions.

Among the issue area controls, the issue of SECURITY proves to be most relevant when it comes to the decision to sign and ratify treaties. ${ }^{20}$ But the decision to sign a treaty is especially dependent on whether SECURITY issues are at stake. A treaty that has a bearing SECURITY matters is between 37 and 56 percent (models 1 and 3 resp.) more likely to be signed than a HUMAN RIGHTS treaty, and more than twice as likely as an ENVIRONMENTAL agreement. SECURITY issues have also a strong ad positive impact on treaty ratification, but the effects are somewhat weaker than those for signature: SECURITY treaties are 18 to 19 percent more likely to be ratified than HUMAN RIGHTS agreements and 43 to 45 percent more than ENVIRONMENTAL agreements (models 6 and 4 resp.).

We also find a robust and statistically significant effect for the variable COMMON LAW. States with a common law system are less likely to sign and ratify multilateral treaties than states with a civil law tradition. We find no robust effects for POST-1989 STATE, either for the event of ratification or the event of signature. GDP P.C. is statistically significant in both types of model, but the fact that its inclusion does not change the major result confirms that UN DIPLOMATIC REPRESENTATION does not merely reflect a state's power, wealth or interest. Our results confirm previous findings regarding states' commitment to individual or sectorspecific treaties. As a final point it is worth mentioning that we tested for the other two alternative factors mentioned above - political constraints (POLCON) and states' material power (CINC). We do not report the results of these tests in the tables as they revealed consistently insignificant effects on both signature and ratification.

\footnotetext{
${ }^{20}$ The hazard ratio is calculated e.g. by $\exp (\operatorname{coef}$ SECURITY $)=\exp (\operatorname{coefHUMAN}$ RIGHTS $)$.
} 
While the analysis of the size of states' diplomatic missions to the UN yields encouraging results, this covariate is an imperfect proxy for what we attempt to measure - a state's actual involvement during specific treaty negotiations. To remedy this, we fitted the same two sets of models for the event of signature (models 1-3) and the event of ratification (models 4-6) with the smaller subset of 'salient' treaties using the more precise TREATYSPECIFIC DIPLOMATIC REPRESENTATION variable (Table 3). The focus on salient treaties is a more crucial test for our argument, as we would expect governments to be especially vigilant during the negotiations of such treaties and therefore to monitor diplomats closely to guard against any potential "ties-that-bind" effect.

\section{[Table 3 about here]}

Results from those models strongly reaffirm the different effects of TREATY-SPECIFIC DIPLOMATIC REPRESENTATION on signature and ratification. The number of diplomats present during negotiations matters substantially for the act of signature - having a positive and highly statistically significant effect on the likelihood of signature. Increasing the size of the delegation by one additional delegate makes signature of a treaty between 1.5 percent (model 3) and 5.3 percent (model 1) more likely; and a state with a many-delegate mission (in the 90th percentile) is between 1.05 (model 3) and 1.17 (model 1) times more likely to sign a treaty than is a state with a small delegation (in the 10th percentile). In the most extreme case, a state with the largest delegation of 52 representatives is between 2.21 (model 3) and 14.71 (model 1) times more likely to sign a treaty than a state that is no represented during negotiations.

Again, we find no such effects for the event of ratification. Although TREATYSPECIFIC DIPLOMATIC REPRESENTATION reveals a statistically significant effect on ratification in model 4, this effect disappears in all subsequent models we fitted. 


\section{Conclusion}

Whereas the question of why states ratify multilateral treaties has received significant attention in scholarly work, the question of why states sign multilateral treaties has been largely neglected. This paper addresses this surprisingly underexplored research area by focusing on how diplomatic participation in negotiations promotes the signature of a treaty.

Although we present a novel explanation for the relationship of diplomatic involvement in multilateral treaty making and treaty commitment, further research is needed on the politics of signature, not least to test more directly the two postulated ties-that-bind pathways and to understand their relative importance.

To start with, we need more systematic data on the types and extent of contributions and interventions during negotiations and their tie-binding effects. This would allow us to carry out a more targeted assessment of the textual overlap between individual delegations' draft proposals and the final treaty text, and to investigate in particular how "ties with the text" effects are generated through treaty participation. For the second incentive ("ties with the diplomatic community"), more information is necessary to trace how mutual expectations develop as a result of "face-to-face diplomacy" (Holmes, 2013). Here, surveys and survey experiments with diplomats would help to understand better the development of this particular tie.

Moreover, additional (and omitted) states' incentives for signature might be detected through case studies. Anecdotal evidence suggests that some framework agreements establish that signatories to the initial agreement can participate in subsequent negotiations over a follow-up protocol. For example, the US as a signatory (but not a ratifying party) of the Rome Statute of the International Criminal Court is entitled to participate in any future negotiations under the treaty framework (Scheffer, 2012). This procedural design feature of having or not having a "seat at the table" could add a strategic relevance to treaty signature. 
Another design feature (the ratification threshold for a treaty's entry into force) might also affect the likelihood of signature. If the threshold is high, sponsors of the treaty could opt for signature as a signal to other states that they want to see the successful entry into force of the obligations negotiated pre-empting any criticism that could arise post negotiations. If sponsors are also powerful states, their signature most likely puts additional pressure on other states to commit.

In conclusion, the findings of this paper and the selected research opportunities sketched above highlight the need for further inquiry into the so far neglected politics of signing multilateral treaties and the role of diplomats in treaty making.

\section{References}

American Non-Governmental Organizations Coalition for the International Criminal Court. 2008. "A Campaign for US Immunity from the ICC." Available at: www.amicc.org/usicc/biacampaign.

Andersen, Per K. and Richard D. Gill. 1982. “Cox's regression model for counting processes: A large sample study." Annals of Statistics 10(4):1100-1120.

Bail, Christoph, Jean Paul Decaestecker and Matthias Jorgensen. 2002. European Union. In The Cartagena Protocol on Biosafety, ed. Christoph Bail, Robert Falkner and Helen Marquard. London: The Royal Institute of International Affairs pp. 166-185.

Ballhorn, Richard. 2002. Canada. In The Cartagena Protocol on Biosafety, ed. Christoph Bail, Robert Falkner and Helen Marquard. London: The Royal Institute of International Affairs pp. 105-114.

Bartos, Otomar. 1996. "Negotiation as friendship formation." International Negotiation 1(1):29-46. 
Benedick, Richard Elliott. 1998. Ozone Diplomacy. New Directions in Safeguarding the Planet. (Enlarged edition). Cambridge: Harvard University Press.

Box-Steffensmeier, Janet M. and Bradford S. Jones. 2004. Event History Modeling. A Guide for Social Scientists. New York: Cambridge University Press.

Central Intelligence Agency. 2008. The World Factbook. Washington, DC: Central Intelligence Agency.

Checkel, Jeffrey T. 2005. "International institutions and socialization in Europe: Introduction and framework.” International Organization 59:801-826.

Correlates of War Project. 2005. "National Material Capabilities, Version 3.02.” Available at: http://www.correlatesofwar.org/.

Falkner, Robert. 2002. Negotiating the Biosafety Protocol: The international process. In The Cartagena Protocol on Biosafety, ed. Christoph Bail, Robert Falkner and Helen Marquard. London: The Royal Institute of International Affairs pp. 3-22.

Goodliffe, Jay and Darren G. Hawkins. 2006. "Explaining Commitment: States and the Convention against Torture." Journal of Politics 68(2):358-371.

Guzman, Andrew T. 2008. How International Law Works. A Rational Choice Theory. New York: Oxford University Press.

Haftel, Yoram Z. and Alexander Thompson. 2013. "Delayed ratification: The domestic fate of bilateral investment treaties." International Organization 67(2):355-387.

Henisz, Witold J. 2000. "The Institutional environment for economic growth.” Economic and Politics 12(1):1-31.

Hollyer, James R. and Peter B. Rosendorff. 2012. "Leadership survival, regime type, policy uncertainty and PTA accession.” International Studies Quarterly 56(4):748-764.

Holmes, Marcus. 2013. "The force of face-to-face diplomacy: Mirror neurons and the problem of intentions." International Organization 57(4):829-861. 
Johnson, Tana. 2013. "Institutional design and bureaucrats impact on political control." Journal of Politics 75(1):183-197.

Johnston, Alastair I. 2001. "Treating international institutions as social environments." International Studies Quarterly 45(4):487-515.

Köster, Veit. 2002. The Biosafety Working Group (BSWG) process: A personal account from the chair. In The Cartagena Protocol on Biosafety, ed. Christoph Bail, Robert Falkner and Helen Marquard. London: The Royal Institute of International Affairs pp. $44-61$

La Porta, Rafael, Florencio López-de Silanes, Andrei Shleifer and Robert W. Vishny. 1999. "The quality of government." Journal of Law, Economics and Organization 15(1):222-279.

Lax, David and James Sebenius. 1986. The Manager as Negotiator: Bargaining for Cooperation and Competitive Gain. New York: The Free Press.

Leinaweaver, Justin. 2012. "The marketing of environmental treaties: Non-binding signature as information and raising public awareness." SSRN.

Lewis, Jeffrey. 2005. "The Janus face of Brussels: Socialization and everyday decision making in the European Union.” International Organization 59(4):937-971.

Marshall, Monty G., Ted R. Gurr and Keith Jaggers. 2014. "Polity IV Project: Political Regime Characteristics and Transitions, 1800-2013.” Available at: http://www.systemicpeace.org/inscrdata.html.

New York Times. 2015. "A reckless act in the Senate on Iran.” New York Times, 14 April 2015. Available at: http://www.nytimes.com/2015/04/15/opinion/a-reckless-act-inthe-senate-on-iran.html. 
Nielson, Daniel and Michael Tierney. 2003. "Delegation to international organizations: agency theory and World Bank environmental reform.” International Organization $57(2): 241-276$

Nobs, Beat. 2002. Switzerland. In The Cartagena Protocol on Biosafety, ed. Christoph Bail, Robert Falkner and Helen Marquard. London: The Royal Institute of International Affairs pp. 186-192.

Pelc, Krzysztof J. 2013. "Googling the WTO: What search-engine data tell us about the political economy of institutions.” International Organization 67(3):629-655.

Rathbun, Brian. 2011. "Before hegemony: Generalized trust and the creation and design of international security organizations." International Organization 65(2):243-273.

Recchia, Steven P. 2002. "International environmental treaty engagement in 19 democracies.” Policy Studies Journal 30(4):470-494.

Sartori, Anne E. 2005. Deterrence by Diplomacy. Princeton, NJ: Princeton University Press.

Scheffer, David. 2012. All the Missing Souls: A Personal History of the War Criminal Tribunals. Princeton: Princeton University Press.

Simmons, Beth A. 2009. Mobilizing for Human Rights. International Law in Domestic Politics. New York: Cambridge University Press.

Szasz, Paul C. 2002. "The Security Council starts legislating." American Journal of International Law 96(4):901-905.

Tableman, Mara and Jong Sung Kim. 2004. Survival Analysis Using S. Analysis of Time-toEvent Data. London: Chapman \& Hall.

The Washington Post. 1997. "Senate Republicans call Kyoto pact dead." Thursday, December 11, 1997. Available at: http://www.washingtonpost.com/wpsrv/inat1/longterm/climate/stories/clim121197b.htm. 
Therneau, Terry M. and Patricia M. Grambsch. 2000. Modeling Survival Data: Extending the Cox Model. New York: Springer Verlag.

Thuysbaert, Prosper. 2006. Diplomatic Skating on Thin Multilateral Ice. Leuven: Acco.

Tomz, Michael. 2007. Reputation and International Cooperation: Sovereign Debt across Three Centuries. Princeton, NJ: Princeton University Press.

United Nations Treaty Collection. 2014. "International Convention for the Suppression of the Financing of Terrorism." New York, 9 December 1999. Available at: https://treaties.un.org/Pages/ViewDetails.aspx?src=TREATY\&mtdsg_no=XVIII$11 \&$ chapter $=18 \&$ lang $=$ en.

United Nations Treaty Collection. 2015. "Glossary of Terms relating to Treaty Actions." Available at: https://treaties.un.org/pages/Overview.aspx?path=overview/glossary/page1_en.xml\#si gnaturesubject.

Vienna Convention on the Law of Treaties. 1969. "1155 U.N.T.S. 331, reprinted in 8 I.L.M. 679 (May 23, 1969)."

Villanova Nogueira, Arthur H. 2002. Brazil. In The Cartagena Protocol on Biosafety, ed. Christoph Bail, Robert Falkner and Helen Marquard. London: The Royal Institute of International Affairs pp. 129-137.

Yang, Philemon. 2002. The follow-up process and the intergovernmental committee for the Cartagena Protocol (ICCP). In The Cartagena Protocol on Biosafety, ed. Christoph Bail, Robert Falkner and Helen Marquard. London: The Royal Institute of International Affairs pp. 76-82. 


\section{Tables}

\begin{tabular}{|c|c|c|c|c|c|c|c|}
\hline rank & signatories & no. & $\%$ & rank & ratifiers & no. & $\%$ \\
\hline 1 & Finland & 42 & 80.77 & 1 & Spain & 39 & 75 \\
\hline 2 & Denmark & 41 & 78.85 & 2 & Romania & 37 & 71.15 \\
\hline \multirow[t]{2}{*}{3} & Sweden & 39 & 75 & & Slovenia & 37 & 71.15 \\
\hline & Germany & 39 & 75 & 4 & Lithuania & 36 & 69.23 \\
\hline 5 & Spain & 38 & 73.08 & & Latvia & 36 & 69.23 \\
\hline \multirow[t]{2}{*}{6} & Netherlands & 37 & 71.15 & 6 & Denmark & 35 & 67.31 \\
\hline & Brazil & 37 & 71.15 & & Norway & 35 & 67.31 \\
\hline \multirow[t]{2}{*}{8} & France & 36 & 69.23 & & Slovakia & 35 & 67.31 \\
\hline & $\begin{array}{l}\text { United } \\
\text { Kingdom }\end{array}$ & 36 & 69.23 & & Hungary & 35 & 67.31 \\
\hline \multirow[t]{3}{*}{10} & Norway & 35 & 67.31 & & Bulgaria & 35 & 67.31 \\
\hline & Italy & 35 & 67.31 & & & & \\
\hline & Luxembourg & 35 & 67.31 & & & & \\
\hline
\end{tabular}

Table 1. Top ten signatory and ratifying states.

Note: Rankings for the top 10 signatory and ratifying states based on 52 multilateral treaties adopted between 1990 and 2005. (no.: number of signatures/ratifications; \%: percentage of signatures/ratifications). States belonging to the group of top 10 signatories and ratifiers are shown in italics. 


\begin{tabular}{|c|c|c|c|c|c|c|}
\hline & \multicolumn{3}{|c|}{ Signature } & \multicolumn{3}{|c|}{ Ratification } \\
\hline & $\begin{array}{c}\text { Model 1 } \\
\exp (\text { coef }) \\
(p) \\
\end{array}$ & $\begin{array}{c}\text { Model } 2 \\
\exp (\text { coef }) \\
(p) \\
\end{array}$ & $\begin{array}{c}\text { Model 3 } \\
\exp (\text { coef }) \\
(p) \\
\end{array}$ & $\begin{array}{c}\text { Model } 4 \\
\exp (\text { coef }) \\
(p) \\
\end{array}$ & $\begin{array}{c}\text { Model } 5 \\
\exp (\text { coef }) \\
(p)\end{array}$ & $\begin{array}{c}\text { Model } 6 \\
\exp (\text { coef }) \\
(p)\end{array}$ \\
\hline \multirow[t]{2}{*}{ UN DIPLOMATIC REPRESENTATION } & 1.019 & 1.008 & 1.008 & 1.005 & 1.000 & 0.9992 \\
\hline & $0.000 * * *$ & $0.006 * *$ & $0.000 * *$ & $0.039 *$ & 0.962 & 0.772 \\
\hline \multirow[t]{2}{*}{ POLITY } & & 1.05 & 1.043 & & 1.038 & 1.031 \\
\hline & & $0.000 * * *$ & $0.000 * * *$ & & $0.000 * * *$ & $0.000 * * *$ \\
\hline \multirow[t]{2}{*}{ POST-1989 STATE } & & 0.873 & 0.712 & & 1.235 & 1.087 \\
\hline & & 0.145 & $0.000 * *$ & & $0.001 * * *$ & 0.323 \\
\hline \multirow[t]{2}{*}{ COMMON LAW } & & 0.673 & 0.716 & & 0.783 & 0.834 \\
\hline & & $0.000 * * *$ & $0.000 * * *$ & & $0.000 * * *$ & $0.007 * *$ \\
\hline \multirow[t]{2}{*}{ GDP P.C. } & & 1.000 & 1.000 & & 1.000 & 1.000 \\
\hline & & $0.000 * * *$ & $0.000 * * *$ & & $0.000 * * *$ & $0.000 * * *$ \\
\hline \multirow[t]{2}{*}{ AMERICA (COMP. EUROPE) } & 0.6 & & 0.786 & 0.703 & & 0.876 \\
\hline & $0.000 * * *$ & & 0.051 & $0.000 * * *$ & & 0.156 \\
\hline \multirow[t]{2}{*}{ AFRICA (COMP. EUROPE) } & 0.481 & & 0.71 & 0.543 & & 0.764 \\
\hline & $0.000 * * *$ & & $0.012 *$ & $0.000 * * *$ & & $0.016^{*}$ \\
\hline \multirow[t]{2}{*}{ ASIA (COMP. EUROPE) } & 0.385 & & 0.624 & 0.502 & & 0.716 \\
\hline & $0.000 * * *$ & & $0.000 * * *$ & $0.000 * * *$ & & $0.001 * * *$ \\
\hline \multirow[t]{2}{*}{ HUMAN RIGHTS } & 5.768 & & 5.156 & 4.677 & & 4.286 \\
\hline & $0.000 * * *$ & & $0.000 * * *$ & $0.000 * * *$ & & $0.000 * * *$ \\
\hline \multirow[t]{2}{*}{ ENVIRONMENT } & 3.706 & & 3.78 & 3.852 & & 3.522 \\
\hline & $0.000 * * *$ & & $0.000 * * *$ & $0.000 * * *$ & & $0.000 * * *$ \\
\hline \multirow[t]{2}{*}{ SECURITY } & 7.93 & & 8.021 & 5.579 & & 5.051 \\
\hline & $0.000 * * *$ & & $0.000 * * *$ & $0.000 * * *$ & & $0.000 * * *$ \\
\hline LRT & 2413 & 949.3 & 2461 & 1785 & 426.2 & 1526 \\
\hline (p) & $(0)$ & (0) & $(0)$ & $(0)$ & $(0)$ & $(0)$ \\
\hline Wald test & 1378 & 219.5 & 1199 & 888.1 & 225.2 & 924.4 \\
\hline (p) & $(0)$ & $(0)$ & $(0)$ & $(0)$ & $(0)$ & (0) \\
\hline \multirow[t]{2}{*}{ Robust (score) logrank test $(p)$} & 153.9 & 44.57 & 128.6 & 158.6 & 60.73 & 127.4 \\
\hline & $(0)$ & $(0)$ & $(0)$ & $(0)$ & $(0)$ & $(0)$ \\
\hline No. Observations & 73086 & 52400 & 52400 & 78187 & 57919 & 58136 \\
\hline No. Events & 3616 & 3173 & 3173 & 4439 & 3595 & 3605 \\
\hline No. States & 192 & 158 & 158 & 192 & 158 & 158 \\
\hline Period & 1990-2008 & $1990-2007$ & 1990-2007 & 1991-2008 & 1991-2007 & 1991-2007 \\
\hline
\end{tabular}

Table 2. Cox proportional hazards models based on full treaty sample.

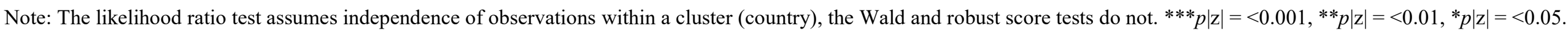




\begin{tabular}{|c|c|c|c|c|c|c|}
\hline & \multicolumn{3}{|c|}{ Signature } & \multicolumn{3}{|c|}{ Ratification } \\
\hline & $\begin{array}{c}\text { Model 1 } \\
\exp (\text { coef }) \\
(p) \\
\end{array}$ & $\begin{array}{c}\text { Model } 2 \\
\exp (\text { coef }) \\
(p) \\
\end{array}$ & $\begin{array}{c}\text { Model 3 } \\
\exp (\text { coef) } \\
(p) \\
\end{array}$ & $\begin{array}{c}\text { Model } 4 \\
\exp (\text { coef }) \\
(p) \\
\end{array}$ & $\begin{array}{c}\text { Model } 5 \\
\exp (\text { coef }) \\
(p) \\
\end{array}$ & $\begin{array}{c}\text { Model } 6 \\
\exp (\text { coef }) \\
(p) \\
\end{array}$ \\
\hline \multirow[t]{2}{*}{ TREATY-SPECIFIC DIPLOMATIC REPRESENTATION } & 1.053 & 1.024 & 1.015 & 1.022 & 0.997 & 1.003 \\
\hline & $0.000 * * *$ & $0.002 * *$ & $0.041^{*}$ & $0.002 * *$ & 0.689 & 0.644 \\
\hline \multirow[t]{2}{*}{ POLITY } & & 1.068 & 1.054 & & 1.049 & 1.041 \\
\hline & & $0.000 * * *$ & $0.000 * * *$ & & $0.000 * * *$ & $0.000 * * *$ \\
\hline \multirow[t]{2}{*}{ STATE } & & 0.885 & 0.808 & & 1.128 & 0.946 \\
\hline & & 0.405 & 0.165 & & 0.188 & 0.646 \\
\hline \multirow{2}{*}{ COMMON LAW } & & 0.667 & 0.753 & & 0.799 & 0.859 \\
\hline & & $0.000 * * *$ & $0.005 * *$ & & $0.022 *$ & 0.139 \\
\hline \multirow[t]{2}{*}{ GDP P.C. } & & 1.000 & 1.000 & & 1.000 & 1.000 \\
\hline & & $0.000 * * *$ & $0.000 * * *$ & & 0.069 & 0.65 \\
\hline \multirow[t]{2}{*}{ AMERICA (COMP. EUROPE) } & 0.639 & & 0.889 & 0.806 & & 0.818 \\
\hline & $0.002 * *$ & & 0.342 & 0.083 & & 0.224 \\
\hline \multirow[t]{2}{*}{ AFRICA (COMP. EUROPE) } & 0.456 & & 0.781 & 0.611 & & 0.739 \\
\hline & $0.000 * * *$ & & $0.027 *$ & $0.000 * * *$ & & 0.05 \\
\hline \multirow[t]{2}{*}{ ASIA (COMP. EUROPE) } & 0.351 & & 0.632 & 0.538 & & 0.679 \\
\hline & $0.000 * * *$ & & $0.002 * *$ & $0.000 * * *$ & & $0.006^{* *}$ \\
\hline \multirow[t]{2}{*}{ HUMAN RIGHTS } & 2.033 & & 1.893 & 1.219 & & 1.229 \\
\hline & $0.000 * * *$ & & $0.000 * * *$ & $0.000 * * *$ & & $0.000 * * *$ \\
\hline \multirow[t]{2}{*}{ ENVIRONMENT } & 0.621 & & 0.673 & 1.736 & & 1.887 \\
\hline & $0.000 * * *$ & & $0.000 * * *$ & $0.000 * * *$ & & $0.000 * * *$ \\
\hline LRT & 588.4 & 519 & 671.3 & 227 & 183.4 & 299.9 \\
\hline (p) & $(0)$ & $(0)$ & $(0)$ & $(0)$ & $(0)$ & $(0)$ \\
\hline Wald test & 361.4 & 221 & 485.4 & 137 & 102.3 & 230.5 \\
\hline & $(0)$ & $(0)$ & $(0)$ & $(0)$ & $(0)$ & $(0)$ \\
\hline \multirow{2}{*}{ Robust (score) logrank test ( $p$ ) } & 103 & 53.96 & 88.91 & 80.97 & 56.6 & 85.92 \\
\hline & $(0)$ & $(0)$ & $(0)$ & $(0)$ & $(0)$ & $(0)$ \\
\hline No. Observations & 9772 & 6671 & 6671 & 12857 & 9562 & 9562 \\
\hline No. Events & 1655 & 1423 & 1423 & 1832 & 1474 & 1474 \\
\hline No. States & 192 & 158 & 158 & 192 & 158 & 158 \\
\hline Period & $1992-2008$ & $1992-2007$ & 1992-2007 & 1992-2008 & $1992-2007$ & 1992-2007 \\
\hline
\end{tabular}

Table 3. Cox proportional hazards models based on sub-sample of salient treaties.

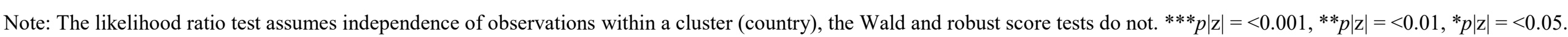




\section{Appendix}

treaty

1 Cartagena Protocol on Biosafety

2 Comprehensive Nuclear-Test-Ban Treaty

3 Convention on Biological Diversity

4 Convention on Nuclear Safety

5 Convention on the Prohibition of the Development, Production, Stockpiling and Use of Chemical Weapons and on1992 their Destruction

6 Convention on the Prohibition of the Use, Stockpiling, Production and Transfer of Anti-Personnel Mines and on their Destruction

7 Convention on the Safety of UN and Associated Personnel

$2000 \quad 0$

19961

19921

19940

International Atomic Energy Agency (IAEA) Joint Conventic

19971

1994

Safety of Radioactive Waste

9 International Civil Aviation Organization (ICAO) Convention on the Marking of Plastic Explosives for the Purpose of1991 0 Detection

10 International Cocoa Agreement

11 International Coffee Agreement

12 International Convention for the Suppression of Acts of Nuclear Terrorism

13 International Convention for the Suppression of Terrorist Bombings

14 International Convention for the Suppression of the Financing of Terrorism

15 International Convention on Maritime Liens and Mortgages

16 International Convention on the Arrest of Ships

20010

$2000 \quad 0$

17 International Convention on the Protection of the Rights of All Migrant Workers and Members of Their Families1990 (ICRMW)

18 International Maritime Organization (IMO) Convention on Liability and Compensation for Damage in Connection1996 0 with the Carriage of Hazardous and Noxious Substances by Sea

19 IMO International Convention on Oil Pollution Preparedness, Response and Co-operation

20 IMO International Convention for the Control and Management of Ships' Ballast Water and Sediments

21 IMO International Convention on the Control of Harmful Anti-fouling Systems on Ships

22 IMO Protional Convention on the Control of Harmful Anti-fouling Systems on Ships 2001 Substances

23 IMO Protocol to the International Convention on Civil Liability for Oil Pollution Damage

24 International Tropical Timber Agreement

25 International Sugar Agreement

26 Kyoto Protocol

$\begin{array}{lll}2001 & 1 & 0 \\ 1994 & 0 & - \\ 1992 & 0 & - \\ 1997 & 1 & 1\end{array}$

Table 4. Selected multilateral treaties.

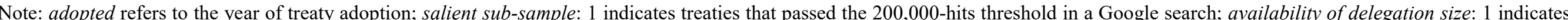

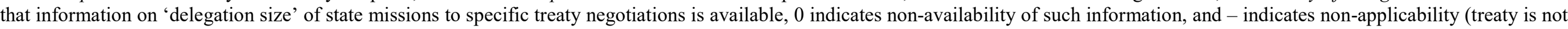
in the salient sub-sample). 
27 Optional Protocol to the Convention on the Rights of the Child on the involvement of children in armed conflict

2000

28 Optional Protocol to the Convention on the Rights of the Child on the sale of children, child prostitution and child2000 pornography

29 Protocol against the Illicit Manufacturing of and Trafficking in Firearms, Their Parts and Components and2001 Ammunition, supplementing the UN Convention against Transnational Organized Crime

30 Protocol against the Smuggling of Migrants by Land, Air and Sea, supplementing the UN Convention against2000 Transnational Organized Crime

31 Protocol to Prevent, Suppress and Punish Trafficking in Persons, Especially Women and Children, supplementing 2000 the UN Convention against Transnational Organized Crime

32 Rome Statute of the International Criminal Court

33 Rotterdam Convention on Prior Informed Consent (PIC) Procedure for Certain Hazardous Chemicals and Pesticides1998 in International Trade

34 Second Protocol to the Hague Convention of 1954 for the Protection of Cultural Property in the Event of Armed1999 Conflict

35 Stockholm Convention on Persistent Organic Pollutants (POPs)

36 UN Convention against Corruption

37 UN Agreement for the Implementation of the Provisions of the UN Convention on the Law of the Sea of 101995 December 1982 relating to the Conservation and Management of Straddling Fish Stocks and Highly Migratory Fish Stocks

38 UN Convention against Transnational Organized Crime

39 UN Convention on Independent Guarantees and Stand-by Letters of Credit

40 UN Convention on Jurisdictional Immunities of States and Their Property

41 UN Convention on the Assignment of Receivables in International Trade

42 UN Convention on the Liability of Operators of Transport Terminals in International Trade

43 UN Convention on the Protection and Use of Transboundary Watercourses and International Lakes

44 UN Convention on the Use of Electronic Communications in International Contracts

45 UN Convention to Combat Desertification

46 UN Framework Convention on Climate Change

47 World Customs Organization (WCO) Revised Kyoto Convention

48 World Health Organization (WHO) Framework Convention on Tobacco Control

49 World Intellectual Property Organization (WIPO) Copyright Treaty

50 WIPO Trademark Law Treaty

51 WIPO Patent Law Treaty

52 WIPO Performances \& Phonograms Treaty

$\begin{array}{lll}2000 & 1 & 1 \\ 1995 & 0 & - \\ 2004 & 0 & - \\ 2001 & 0 & - \\ 1991 & 0 & - \\ 1997 & 0 & - \\ 2005 & 0 & - \\ 1994 & 0 & - \\ 1992 & 1 & 1 \\ 1999 & 0 & - \\ 2003 & 1 & 1 \\ 1996 & 0 & - \\ 1994 & 0 & - \\ 2000 & 0 & - \\ 1996 & 0 & -\end{array}$

Table 4 (continued). Selected multilateral treaties. 


\begin{tabular}{llllll}
\hline \multicolumn{6}{c}{ UN DIPLOMATIC REPRESENTATION } \\
rank & country & mean & sd & min & max \\
\hline 1 & USA & 116 & 12.18 & 81 & 129 \\
2 & Russia & 82 & 6.98 & 68 & 93 \\
3 & China & 66 & 4.57 & 59 & 75 \\
4 & Germany & 57 & 5.74 & 41 & 66 \\
5 & Japan & 50 & 5.85 & 32 & 59 \\
6 & Cuba & 40 & 3.04 & 35 & 45 \\
7 & United Kingdom & 36 & 3.86 & 25 & 41 \\
8 & Brazil & 33 & 3.17 & 25 & 37 \\
9 & Korea & 31 & 3.43 & 17 & 36 \\
10 & France & 30 & 2.70 & 22 & 35 \\
\hline
\end{tabular}

TREATY-SPECIFIC DIPLOMATIC REPRESENTATION

\begin{tabular}{llllll} 
rank & country & mean & sd & min & max \\
\hline 1 & Japan & 13 & 7.95 & 0 & 29 \\
2 & USA & 12 & 8.66 & 0 & 27 \\
3 & Germany & 11 & 14.12 & 0 & 52 \\
& Italy & 11 & 8.15 & 0 & 20 \\
5 & France & 10 & 6.37 & 0 & 15 \\
& United Kingdom & 10 & 6.00 & 0 & 19 \\
7 & Russia & 9 & 7.23 & 0 & 32 \\
8 & Australia & 8 & 9.86 & 0 & 29 \\
& Austria & 8 & 5.45 & 0 & 17 \\
& Canada & 8 & 7.87 & 0 & 27 \\
\hline
\end{tabular}

Table 5. Top ten states' (averaged) diplomatic missions to the United Nations and specific treaty negotiations.

Note: mean: number of representatives in a state's diplomatic mission to the United Nations averaged over time, and for treaty-specific negotiations averaged over treaties; $s d$ : standard deviation; min: a state's minimum size of a diplomatic mission, max: a state's maximum size of diplomatic mission.

Table 5 provides the average size of diplomatic representations to the United Nations and to specific treaty negotiations for the top 10 countries. The size of diplomatic missions to the United Nations (averaged over time) varies considerable for the top-ten group - from 30 representatives for France to 112 representatives for the United States. Although the differences between states for the treaty-specific missions (averaged over treaty negotiations) are somewhat smaller, the standard deviations for individual states are relatively large indicating a great variation across treaties. Overall both variables are distributed unevenly as shown in Figure 1, below. 

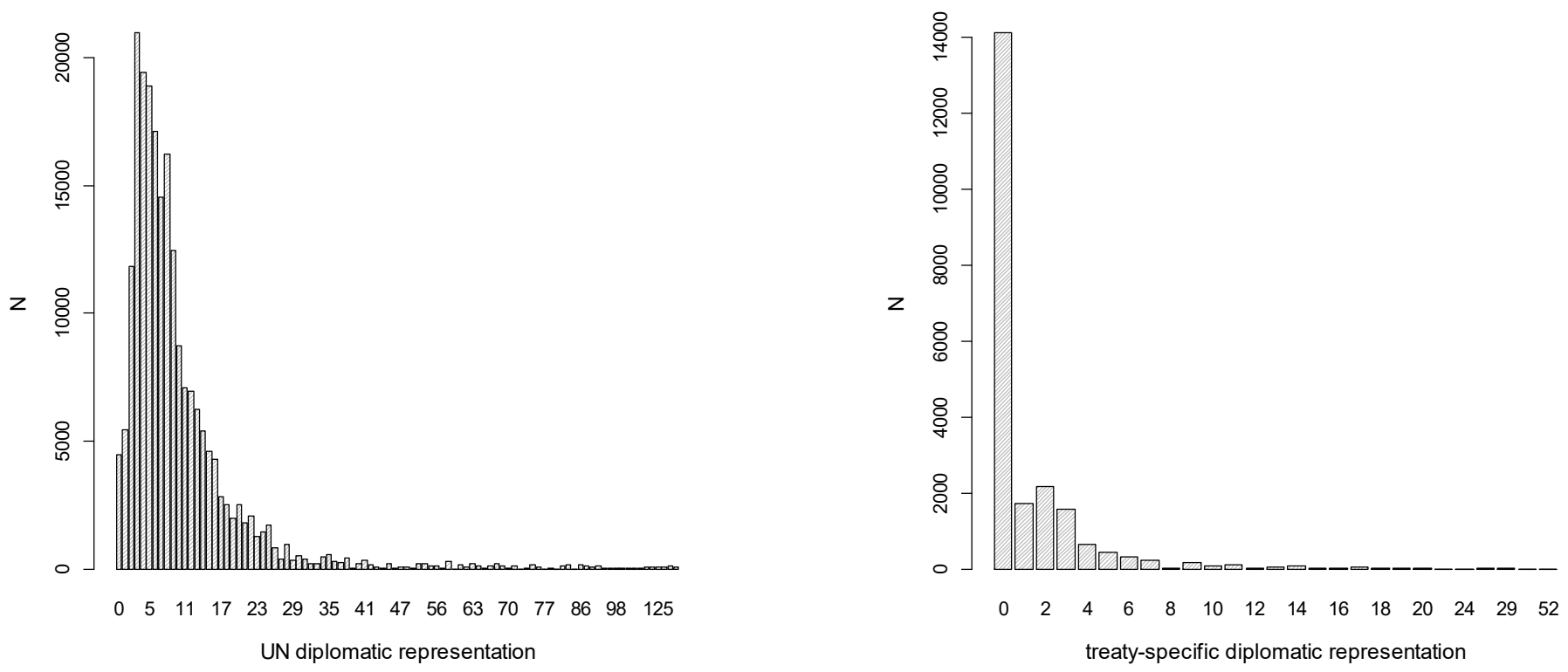

Figure 1. Distribution of UN DIPLOMATIC REPRESENTATION and TREATY-SPECIFIC DIPLOMATIC REPRESENTATION variables. 


\begin{tabular}{|c|c|c|c|c|c|c|c|c|}
\hline & \multirow[b]{2}{*}{$\min$} & \multicolumn{3}{|c|}{ Signature } & \multicolumn{3}{|c|}{ Ratification } & \multirow[b]{2}{*}{ obs. } \\
\hline & & $\max$ & mean & $s d$ & obs. & mean & $s d$ & \\
\hline \multicolumn{9}{|c|}{ Key explanatory variables } \\
\hline $\begin{array}{l}\text { UN DIPLOMATIC } \\
\text { REPRESENTATION }\end{array}$ & 0 & 129 & 9.91 & 11.49 & 73086 & 10.87 & 13.04 & 78187 \\
\hline $\begin{array}{l}\text { TREATY-SPECIFIC } \\
\text { DIPLOMATIC } \\
\text { REPRESENTATION }\end{array}$ & 0 & 52 & 1.04 & 2.44 & 9772 & 1.6 & 3.52 & 12857 \\
\hline \multicolumn{9}{|l|}{ Control variables } \\
\hline POLITY & -10 & 10 & 2.11 & 6.73 & 53129 & 2.50 & 6.69 & 58626 \\
\hline POLCON & 0 & 0.9 & 0.38 & 0.32 & 55069 & 0.4 & 0.33 & 60395 \\
\hline POST-1989 STATE & 0 & 1 & 0.15 & 0.36 & 73628 & 0.14 & 0.34 & 78729 \\
\hline COMMON LAW & 0 & 1 & 0.35 & 0.48 & 73628 & 0.33 & 0.47 & 78729 \\
\hline GDP P.C. & 500 & 34200 & 6068.75 & 7105.51 & 72277 & 6590.07 & 7612.37 & 77409 \\
\hline CINC & 0 & 0.16 & 0.005 & 0.01 & 27782 & 0.01 & 0.2 & 31381 \\
\hline REGION (CATEGORICAL) & 1 & 4 & 2.70 & 1.06 & 73628 & 2.65 & 1.07 & 78729 \\
\hline HUMAN RIGHTS & 0 & 1 & 0.11 & 0.32 & 73628 & 0.12 & 0.33 & 78729 \\
\hline SECURITY & 0 & 1 & 0.20 & 0.40 & 73628 & 0.22 & 0.42 & 78729 \\
\hline ENVIRONMENT & 0 & 1 & 0.36 & 0.48 & 73628 & 0.34 & 0.47 & 78729 \\
\hline
\end{tabular}

Table 6. Explanatory variables in the signature and ratification models.

Note: $s d$ refers to the standard deviation; obs. to numbers of observations. 


\begin{tabular}{lllllll}
\hline country & treaty & adopted & start & stop & status & interval \\
\hline Ireland & CBD & 1992 & 1992 & 1993 & 0 & $(1 ; 2+]$ \\
Ireland & CBD & 1992 & 1993 & 1994 & 0 & $(2 ; 3+]$ \\
Ireland & CBD & 1992 & 1994 & 1995 & 0 & $(3 ; 4+]$ \\
Ireland & CBD & 1992 & 1995 & 1996 & 1 & $(4 ; 5]$ \\
Slovakia & CBD & 1992 & 1993 & 1994 & 1 & $(2 ; 3]$ \\
Ireland & UNCAC & 2003 & 2003 & 2004 & 0 & $(1 ; 2+]$ \\
Ireland & UNCAC & 2003 & 2004 & 2005 & 0 & $(2 ; 3+]$ \\
Ireland & UNCAC & 2003 & 2005 & 2006 & 0 & $(3 ; 4+]$ \\
Ireland & UNCAC & 2003 & 2006 & 2007 & 0 & $(4 ; 5+]$ \\
Ireland & UNCAC & 2003 & 2007 & 2008 & 0 & $(5 ; 6+]$ \\
Slovakia & UNCAC & 2003 & 2003 & 2004 & 0 & $(1 ; 2+]$ \\
Slovakia & UNCAC & 2003 & 2004 & 2005 & 0 & $(2 ; 3+]$ \\
Slovakia & UNCAC & 2003 & 2005 & 2006 & 1 & $(3 ; 4]$ \\
\hline
\end{tabular}

Table 7. Excerpt of the count data.

Note: The Ireland-CBD and Slovakia-UNCAC cases are untruncated and uncensored data examples; the Ireland-UNCAC example is right-censored (no ratification at the end of period of analysis); and the SlovakiaCBD case is left-truncated (exists since 1993).

treaty $\quad \mathrm{CBD}-$ Convention on Biological Diversity; UNCAC - UN Convention against Corruption.

adopted Year in which treaty opened for ratification.

start Begin of the year count.

stop End of the year count.

status 1: ratification; 0 : no ratification.

interval The interval (start, stop] is open on the left and closed on the right; it indicates begin and end of the count (based on the year 1974 when treaty opened for ratification) for each treaty within a country. + indicates the incomplete nature of the data (no event or right-censoring). 